\title{
The Contribution of Art Museums to Art Education
}

\author{
Bassam N. Al-Radaideh \\ College of Education, Department of Curriculum and Instruction-Art Education, \\ Sultan Qaboos University, Code: 123, P.O. Box: 32 Al Khoudh, Muscat, Oman
}

\begin{abstract}
Over the years, in recognition of the need to increase opportunities for art education and art learning, schools have endorsed the value of museum learning and its role in facilitating knowledge acquisition and enriching the educational experience of students. Nevertheless, Jordanian schools ignored the enormous advantages of art museums and they consider them as an additional resource for classroom art. The intention of this study is to activate the role of art museums in art education, as such, the study analyzed contribution of art museum as an integral part in teaching art to students and children in particular. Moreover, the issue of educational tours and school visits to art museums were discussed. In order to establish a base for discussion, books and articles on this subject were reviewed. The study revealed that museum learning is not a supplement to art curriculum, instead, museums are a parallel educational system to schools and they have their own potentialities for providing quality programs, therefore, they should be an integral part of any school art curriculum. Collaboration between schools and art museum is the key to achieve a successful art teaching and learning, where students and children acquire different skills as communication, self-expression, criticism and aesthetic judgment.
\end{abstract}

Keywords: Art Museum, Museum Learning, Art Education, Children Education, School-Museum Collaboration

\section{INTRODUCTION}

Learning can no longer be restricted to books or imparted within the school walls in a planned, sequenced and intentional manner. Learning occurs in a variety of settings and in different informal contexts, such as the home, the street, the museum among others. Over the years, schools recognized the need to increase opportunities for learning and all kinds of extracurricular activities as visits and fieldwork; so the whole environment is considered a learning resource and art museums is part of this wide environment.

Museums are undoubtedly one of the most important learning facilities of society and are a commonly visited and highly valued venue for school excursions. With increasing awareness about museums as valuable resource of knowledge, schools recognized that art curriculum can be compromised with opportunities of learning at the museum. Learning about art from actual art works in the museum and galleries have come to be viewed as valuable to students at all levels from $\mathrm{K}$ college level.

While such a view is gaining increasing popularity all over the world and across the United States, there is still schools especially in the Middle East region ignored the enormous advantages and possibilities of art museums to students especially children, they were excluded from the museum world. Museums were treated as an extra or as additional resource for classroom art. For instance, the instructional potential of Hashemite Kingdom of Jordan art museums and galleries were not taken advantage of; if a visit to art museum took place it takes a shape of field trip model, without any proper preparation from either the teacher or the museum educator, the art works were selected randomly without specific criteria and students simply walk in silence between paintings or display cases, trying to see everything, ending up not seeing anything, because neither the necessary time nor the resource are made available to feel. Eggemeyer 
(2006) stated that in a study of teenage attitudes about museums, it revealed that teens have negative experiences with learning in the museum. Teen respondents recounted feelings of boredom, how they rushed through exhibits and not given enough time to explore and understand art works. Eggemeyer explain that the teenage attitudes speak of a deficiency in the teacher's experience to manage a group of students to learn in an informal environment, the museum environment and their failure to nurture the interest of students during a museum visit.

This study will address the contribution of art museums as a resource in teaching art to students in general; with taking into consideration the childhood level since their experiences laid the foundation for further adult learning. Also the educational tours to art museums will be discussed. Moreover, the study will address the collaboration between schools and museums to achieve the goals and objectives of art education.

\subsection{The Museum Role in Art Education}

Presently, there is a reform in instructional methods and how art is acquired. Formal schools and conventional methods of instruction in the classroom limited access to the vast body of art knowledge. Griffin (2004) states that a school curricula emphasis verbal language and linear symbolic system, while younger generations are much more familiar with visual metaphors. Hence, the school offers almost no visual culture while art museum has a particular relevant contribution in the visual era.

The year 1969 was important for the field of museum education because of changes made to this idea that museums can serve educational purposes. Some pioneering minds in museum education such as Charles Wilson Peale, George Brown Goode and John Cotton Dana suggested that museums should function as educational institutions. The educational role of museums in America was extensively discussed in 1969 by the American Association of museums and recommendations were made and published by the organization. Also, United Nations Educational Scientific and Cultural Organization (UNESCO) made contributions in 1973 by arguing that since museum education would begin to form a regular part of any art curriculum and educators have the responsibility for student's energies and emotional responses to be properly channeled. As a result, the proper use of museum collection requires shared responsibility and a special skill on the part of both the museum and the teaching staff (Berry and Mayer, 1989).

Many books and articles have been written about the uniqueness of museums in general and the integration of museum services with educational role in particular. In light of the integration, many recommendations were given regarding both the roles of museums and the importance of having art teachers from public schools to do some of their teaching in the museum. According to Goodman (1985) art museums are especially important for art education, because viewing art, touching and seeing originals is the most fundamental source of artistic inspiration. Although students may obtain an accurate idea about many works of art through reproductions, nothing can replace seeing the pieces themselves. The ideas learned with the use of real objects are absorbed easily and with greater enthusiasm and remembered longer and generate a thirst to know more.

Art museums implement different learning strategies, as workshops and active learning of all sorts; they aim to offer the students an experience that is not possible elsewhere. There are certain kinds of learning activities that are easy to implement in a museum environments which have the added advantage of having real things to observe, record, appraise and analyze. Educational programs in museum settings encourage students to interact with art works in meaningful ways. Trimis and Savva (2004) wrote "with the advent of Discipline Based Art Education (DBAE), student contact with original works of art was considered central to curriculum planning and art museums became of particular importance in the study of art" (P.20). Art museum is the perfect place for school teachers to teach the four disciplines of art history, art criticism, aesthetics and art production which create a balanced curriculum (Al-Amri, 2010).

Several authors such as Weier (2004); Walsh-Piper (1994); Johnson (1990) and Muhlberger (1985) among others pointed out that museums are one of the few types of institutions where significant learning could occur with the potential to compensate for insufficient art education. Hirzy (1996) clarified that viewing art might serve a greater purpose in education than memorizing the body of knowledge attached to the great art. Through visiting museums students will gain some benefits including: Developing aesthetic awareness through sharpening students' sensibilities and strengthening their power of self-expression; developing a sense of connection to art and building confidence about constructing their own meaning from art works; learning from discussions of art works with classmates and providing motivation for future art making (Al-Radaideh, 2007). 
Visual Understanding in Education (VUE) mentioned in their article" Understanding the Basics" when students encounter actual art work in a museum setting, they learn and acquire visual thinking skills through looking at art, responding to developmentally- based question and participating in group discussion that are facilitated by educators. Learning visual thinking skills under teacher supervision is a valuable tool for developing self-reflective practice and strengthens the students teaching experience (VUE, 2001). Looking and talking about art with others teach students critical and creative thinking; communication skills and visual literacy. Cognitive operations also grow in a relatively short time specially observing, speculating and reasoning on the basis of evidence. Furthermore, students will demonstrate effect $\mathrm{s}$ of academic areas beyond the arts (Eggemeyer, 2006).

\subsection{The Importance of Museum Education in Children Lives}

Art museums plays a vital role in children lives; because they can provide the factual and conceptual knowledge that children seek in a language they can use; the language of seeing and feeling. When tacking child to and art museum, it stimulate his thoughts and imagination, pose questions, arouse his curiosity so that he wishes to penetrate ever more deeply the meaning of what he is exposed to in the museum, it gives him chance to admire in his own good time things which are beyond his ken and, most of all, give him a feeling of awe for the wonders of the world (Black et al., 2006).

According to Gray (1998) art museums are institutions that can make a significant contribution to children's education. It plays an exciting and vital role in nurturing the future generation aesthetically. When children exposed early to original art works especially through the schools, it results in later participation as an adult. Vallance (2007) affirms that in the hands of excellent teachers and museum educators, museums can represent the ultimate goal of art education which is making students lifelong participants in the arts resources available in their communities, long after they left schools.

Many students from preschool through high school visit the museum each year. Hooper-Greenhill (1991) pointed out "for all students, going to a new place, meeting new people, experiencing new approaches to gathering information and encountering real things can be a very stimulating and motivating and can put the knowledge [children] have gained at school into perspective". (p. 52). When children are given the opportunity of exposure in the museum and allowed to have direct contact with actual and different art works, they can be affected in ways that cause them meaningful learning by using their minds, senses and bodies to respond to and interpret art works. Allowing children to handle objects from the museum collection can be beneficial. This form of direct contact greatly enriches children aesthetic experience and enhances children's appreciation of the art work by allowing the child to feel the colors, brush strokes and texture of the piece (Black et al., 2006).

Hurwitz and Day (2007) suggested that specific action should be undertaken by museums and art teachers in collaboration with early childhood professionals to ensure that young children conception of museum will attract them to continuing involvement with museums. Museums can organize special programs and activates for children to cause more museum visitation, such as exhibitions that have forms and images children can easily understand and interpret. Some of those exhibitions use special labeling, taped sound and include visual devices that attract children attention. These kinds of exhibitions teach children to self instruct by instilling the feeling of comfort and belonging.

Creating studio space and workshop of many kinds are also very stimulating to children. In these places, children can meet to interact, enjoy competing with themselves and do different kinds of creative activities by modeling, painting and drawing. Likewise, museum can offer classes and courses for children and their parents. These courses will teach children art history and appreciation. Griffin (2004) stated that museums can also publish good quality reproductions of pictures, posters and manuscript material. It is important to do so because it reminds the child of his or her visit to the museum, it also inculcates a sense of ownership in children.

Griffin (2004) summarizes many benefits of museums for children as:

- The school visit to a museum compliments and facilitates children learning about art and transfer, in some cases, to adult (parents and relatives) visit

- Children develop a sense of connection to art and build confidence about constructing their own meaning from art works

- Children become conversant with critical, appreciation and skills of being able to communicate their feeling about art

- Children learn from the engagement in the discussions of art works with their classmates 
- Museum provides workshops with ample opportunities for children to experience and demonstrate abilities and skills that otherwise are readily available in formal classroom

- Children level of achievement and their aesthetic understanding will increase, for example, seeing the contemporary art works in a museum will stimulate children to write and acquire more knowledge about what they saw

- Children can be influenced to attempt producing art that before now they did not produce

- Museums will increase children's sensitivity to beauty and their environment

- The fine sense of discrimination from sampling different art works in the museums can transfer to good taste and love of exquisite things

The above benefits, if properly harnessed, will do a life time of good to children. The benefits can be reaped through exposure and supported by educational structure. Walsh-Piper (1994) confirmed that "...the integration of seeing, analyzing, responding to and valuing works of art should give students a sense of participation and active discovery that is intimately connected to the general increase of knowledge in their lives" (p. 114).

\subsection{Educational Tours to Art Museums}

Learning about art in the museum is a different kind of learning from the one in the classroom. Art teachers do not need to load children's minds with facts because of examination for accountability purposes. Teacher rather teaches the students to observe, question and talk about art. Because this approach is user friendly in the museum environment, teachers should find ways to motivate students and encourage them to relax, focus, listen and be part of the discussion when it unfolds.

The promotion of active learning in the museum for students begins with planning the visit. A carefully planned visit greatly enhances the value of the learning experience. Griffin (2004), affirms that a successful visit to a museum or art gallery is the result of careful preparation; otherwise a student maybe put off visiting museum for good. Planning a museum tour includes many steps; starting with obtaining permission to tour or do a class in a museum; visiting the museum before the setting to become familiar with the building and collection, making arrangements with the museum staff and selecting exhibits based on specific theme to show to students.

Miner (1995) mentioned in crafting a tour that all tours should be designed to include a beginning, middle and an end. In other words, tours should have introduction to prepare the students for the visit, the lesson theme and the purpose of the lesson. In order to prepare the students for a visit, teachers should give them historical information about the museum; explain where it is located, what kind of exhibition it has, as well as describing the kind of art they are going to see.

It is impossible to define an ideal strategy for a school visit to an art museum because so many variables have to be taken into account. Basically, the activities selected for the students must be compatible with clearly defined goals for the visit and the school curriculum and the selection of a particular exhibit should depend on a specific theme (RTD, 2011). Although all the information acquired during a museum visit is beneficial, it will not be absorbed if it is not sufficiently structured and there is no clear educational aim. According to Alves (2006) educational tours must have precise aims and must be prepared by a person who is acquainted with the collection and has good communication skills, such as the museum educator or the class teacher. The museum educator has the advantage of knowing the collection better, while a teacher is more aware of student educational difficulties and can therefore adapt the tour to their level of knowledge more accurately. Collaboration between the museum educator and the art teacher will ensure the success of the educational tour in a museum setting.

What occur during each class journey to the museum is critical and educators are trained to insure that these journeys are beneficial. Usually, students are confused in a museum environment especially at first entrance; therefore, art teachers have to create an atmosphere from which students can feel that their experience will be exciting and beneficial. Hurwitz and Day (2007) wrote "your students should not be among those who feel they must plod dutifully through galleries or museums. They should, instead, welcome the experience as resulting from being in an effective art program" (p.320).

Teachers should allow students the opportunity to explore and to study the art works for a few minutes, then asking questions that stimulate their responses such as; what is going on in this picture? What do you see that makes you say that? What more can we find? Where do you see that? How do you know that from the picture? Also, students should be given the opportunity to ask questions. It's important that teacher listen to all the comments that students make to assure their important contribution. Vallance (2007) clarifies that the most important part in the aesthetic experience is asking students to look and share responses of art work, because it will develop self-awareness of the process of responding to works of art. 
Once the initial exposure activity occurs, teachers begin to integrate the exhibition into core content areas of the grade curriculum. Walsh-Piper (1994) said "The alert teacher will be aware of his or her students' individual responses to both planned and unplanned elements of the tour, turning as many as possible into learning opportunities (p.112). Students will be asked to search for clues about the theme chosen for study and to explain how the theme was illustrated by images. Also, students will be encouraged to visually analyze components, determining how these come together to produce a whole thought. This will develop a sense of visual literacy for the theme, as well as sharpening critical thinking skills in an innovative and instructive manner (Trivitayakhun, 2010).

At the end of the tour, a discussion should follow that focus on reviewing what the lesson was about, its purpose and what students learned from the visit. Teachers might ask students to produce a particular learning product to demonstrate their own grasp of the concept. This could take the form of an individual or group project that illustrates the students perspectives on theme presented in the exhibition.

\subsection{School- Museum Collaboration}

The museum education is more than an extension of traditional schooling and it is necessary to place the museum and its contents at the center of teaching experience. According to Trimis and Savva (2004); Stone (1996); Hooper-Greenhill (1991) and Hicks (1986), among others, art museum education should be central to art programs in schools and should not be treated as an enrichment, supplement, or resource for the classroom-based art program.

The United States took the lead in uniting the forces of schools at all levels and museums to form schoolmuseum collaboration. A School District 24 in Queens, New York, designed school-museum collaboration for a thematic learning unit on Asian study, which included, among other core competencies, social studies and art history. So the school district and the museum had joined together on a number of educational projects over a period of several years and thus had a framework upon which to expand into more structured long-term schoolmuseum collaboration (Piro, 1997).

Museums have familiarized themselves with the needs of schools and projects that have broadened learning experiences of students are being developed. However, integrating the fields of museums and schools and then teaching a subject effectively leads to the need for a framework to serve a guide during this process.
The literature reveals that many art museums design programs for schools without their participation. Piro (1997) clarifies that the first step in school-museum collaborations are the initial planning sessions conducted between the school and museum. During this session, a planning team of representatives from both school and museum meet to discuss exactly what will take place, the long- and short-term goals for the collaboration and how a learning experience could develop. Both the museum environment and the school curricula should be considered when choosing effective educational methodologies, because it is through careful planning between museums and schools that successful teaching of a subject in a museum setting emerges. Milligan and Brayfield (2004) asserted that art museums make the most of the situations when they present lessons that are keyed into a classroom teacher's educational objectives rather than to the objectives of the museum.

Teacher training in an art gallery or museum is an important component of any collaboration and it has several advantages; it demonstrates to teachers how to use a museum effectively, transforming it into an extension of their classroom. Also, it allows teacher to view the art firsthand in order to better teach their students when they return to the museum with their classes (Griffin, 2004). Most important, it help teachers to expand their role in the museum setting, serving as guide and explainer to their student during their visit without overreliance upon a member of the museum staff.

One of the advantages of the collaboration is initiating a multiple visit where students are able to develop in-depth familiarity with the museum collection (Griffin, 2004). To prepare for these multiple visits, discussions between teacher and museum-educator occur, centering on how the exhibition could be fused to learning experiences while also allowing social interaction between museum-educator and students.

It is through school-museum collaboration a purposeful learning occurs, with more focused knowledge and deepened appreciation of art. I believe with such collaboration, school curricula will be energized, teacher professionalism will be enhanced and students will be engaged in imaginative hands-on learning.

\section{CONCLUSION}

Museum learning is an instructional practice that gaining increasing popularity in schools everywhere. Nevertheless, there are schools in the Middle East region neglected the advantages and possibilities of art museums and they relied only on the classroom teaching which provide students with visual and oral experience alone. 
This research revealed that art museum learning is not an extra or an additional resource for classroombased art programs. Instead, art museums are a parallel educational system to schools, which provide real-life learning experiences and have their own strength and potentialities for providing quality programs that sometimes go beyond school curricula. As such, there is a need to rethink the current methods of teaching art to students in Jordan as a part of the Middle East area; art museum learning should be an integral part of all school programs and it should form a regular part of any art curriculum.

Viewing original works of art in a museum setting make a significant contribution to the education of art students in general and children in particular, unlike in the school classroom; Where students acquire different skills such as communications, criticism, self-expression and aesthetic judgment. There is a need to expose children to museum learning in a regular basis, because museums enrich their learning experience visually and intellectually.

It is difficult to define an ideal strategy for a school visit to an art museum because many variables to be taken into account. Nevertheless, defining a good practice in a museum setting will form positive learning opportunities for students such practices includes: Planning a museum tour, clear educational aim, selection of a particular exhibition depend on a specific theme, asking questions and responding to student and a collaboration between the museum educators and art teachers. In the collaboration between art museums and schools, the goals of school-related programs offered by the museum need to be considered carefully so that each institution benefits and grows. Through school-museum collaboration a purposeful learning occurs, with more focused knowledge and deepened appreciation of art.

Art teacher is the key element for a successful museum setting. Therefore, the art education departments at the Jordan universities should suggest museum education courses for teaching and preparing preservice art teachers to teach in art museums settings, in order to acquire the confidence, knowledge and the experience that comes with training and practicing.

\section{REFERENCES}

Al-Amri, M., 2010. Evaluating art studio courses at Sultan Qaboos University in light of the discipline based art education theory. J. Instructional Pedagog.

Al-Radaideh, B.N., 2007. Conceptualizing approaches to teaching college printmaking utilizing perspectives on learning from k-12 art education. Visual Art Res., 33: 92-99.
Alves, L., 2006. Potential contribution of art museums to art education. Proceedings of the Comunicacao Apresentada no International in SEA Congress (CAIISEAC' 06), Interdisciplinary Dialogues in Arts Education, Viseu.

Berry, N.W. and S.M. Mayer, 1989. Museum Education History, Theory and Practice. 1st Edn., National Art Education Association, Reston. VA., pp: 257.

Black, S., C. Brown and M. Frank, 2006. Teaching teachers to teach in museums: The art of special education. Proceedings of the Annual Meeting of the American Association of Colleges for Teacher Education, Jan. 26-26, All Academic, Inc.

Eggemeyer, V., 2006. Art Museum Resources and Teacher Use. University of North Texas.

Goodman, N., 1985. The end of the museum? J. Aesthetic Educ., 19: 53-62.

Gray, C., 1998. Hope for the future? Early exposure to the arts and adult visits to art museums. J. Cultural Econ., 22: 87-98. DOI: 10.1023/A:1007597717190

Griffin, J., 2004. Research on students and museums: Looking more closely at the students in school groups. Sci. Educ., 88: 59-70. DOI: $10.1002 /$ sce. 20018

Hicks, E.C., 1986. Museums and schools as partners. ERIC Clearinghouse on Information Resources.

Hirzy, E.C., 1996. True Needs, True Partners: Museums and Schools Transforming Education. 1st Edn., Institute of Museum Services, Washington DC., pp: 80.

Hooper-Greenhill, E., 1991. Museum and Gallery Education. 1st Edn., Leicester University Press, Leicester, ISBN-10: 0718513061, pp: 213.

Hurwitz, A. and M. Day, 2007. Children And Their Art: Methods for the Elementary School. 8th Edn., Cengage Learning, Australia, Belmont, CA., ISBN10: 0495006963 , pp: 438.

Johnson, K., 1990. Conferring power: Discipline based art education visits the museum. The J. Paul Getty Trust Bull., 5: 8-9.

Milligan, M.J. and A. Brayfield, 2004. Museums and childhood: Negotiating organizational lessons. Childhood, 11: 275-301. DOI: 10.1177/0907568204040183

Miner, S., 1995. Off to a great start. Docent Educ.

Muhlberger, R., 1985. After art history, What? A personal view of the shaping of art museum education. J. Aesthetic Educ., 19: 93-103.

Piro, J., 1997. School-Museum Collaboration: A passage to Asian study. Educ. Asia, 2: 14-20. 
RTD, 2011. Best practice outside the classroom: How EOTC educators see best practice in their roles. Proceedings of the 2011 MEANZ and NSTP Workshop Roadshow Best Practice and New Directions, Jan. 27-Feb. 4, University of Otago, New Zealand.

Stone, D.L., 1996. Preservice art education and learning in art museums. J. Aesthetic Educ., 30: 83-96. DOI: $10.2307 / 3333323$

Trimis, E. and A. Savva, 2004. The in-depth studio approach: Incorporating an art museum program into a pre-primary classroom. Art Educ., 57: 20-24.

Trivitayakhun, P., 2010. Artistic thoughts: Developing critical thinking through art. The Post Publishing PCL.
Vallance, E., 2007. Museums and Cultural Centers. In: International Handbook of Research in Arts Education, Bresler, L. (Ed.), Springer, the Netherlands, ISBN-10: 1402029985, pp: 673-677.

VUE, 2001. Understanding the Basics.

Walsh-Piper, K., 1994. Museum education and the aesthetic experience. J. Aesthetic Educ., 28: 105115. DOI: $10.2307 / 3333404$

Weier, K., 2004. Empowering Young Children in Art Museums: Letting them take the lead. Contemporary Issues Early Childhood, 5: 106-116. DOI: 10.2304/ciec.2004.5.1.2 